Personalidade Acadêmica Homenageada:

Augustus B. Cochran III (Agnes Scott College)

\title{
CRÉDITOS NÃO SUJEITOS À RECUPERAÇÃO JUDICIAL SOB A PERSPECTIVA DA ANÁLISE ECONÔMICA DO DIREITO
}

\section{CREDITS NOT SUBJECT TO JUDICIAL RECOVERY UNDER THE PERSPECTIVE OF THE ECONOMIC ANAL YSIS OF LAW}

\section{ALCIDES WILHELM}

Advogado e Mestrando no curso de Direito Empresarial e Cidadania do Centro Universitário Curitiba - UNICURIIBA. Curitiba - PR. E-mail: alcides@wilhelm.adv.br

\section{RESUMO}

O instituto da recuperação judicial foi positivado por intermédio da Lei 11.101/2005, substituindo o vetusto Decreto-lei 7.661/1945, que há muito tempo já não correspondia às necessidades das empresas em crise, sendo que, invariavelmente, elas sucumbiam perante a situação que se encontravam. Este novo diploma legal trouxe modernidade para o Direito Concursal brasileiro, adotando procedimentos completamente diversos dos até então vigentes, alinhando a nova lei com os institutos correspondentes das principais economias mundiais. Incorporou ao seu texto os princípios constitucionais da preservação da empresa, do tratamento diferenciado às microempresas e empresas de pequeno porte (VILLAS BÔAS; MARUCO, 2018, p. 367) (i), da proteção ao trabalho, da função social da propriedade, entre outros. A finalidade do estudo é verificar se a nova norma legal atinge os objetivos propostos devido a não sujeição de determinados créditos à recuperação. $\mathrm{A}$ metodologia utilizada na pesquisa foi o estudo bibliográfico e documental. $\mathrm{O}$ artigo 47 da lei determina que a recuperação judicial tem por objetivo a superação da situação de crise, a fim de manter a fonte produtora, os empregos, os interesses dos credores, 


\section{Personalidade Acadêmica Homenageada:}

Augustus B. Cochran III (Agnes Scott College)

promovendo a preservação da empresa, trazendo em seu texto os princípios norteadores do instituto. No artigo 49, caput, a lei determinou que todos os créditos, vencidos ou vincendos, seriam submetidos ao instituto, porém, os seus parágrafos (3ํㅜㄴ e $\left.4^{\circ}\right)$ trouxeram várias exceções à regra, determinando que créditos com garantia fiduciária, arrendamento mercantil, com reserva de domínio, adiantamento de contrato de câmbio, entre outros, não seriam sujeitos aos efeitos da recuperação judicial. Também os tributos foram excluídos, conforme disposto no artigo 6ํㅜㄹ parágrafo $7^{\circ}$. Com isso o legislador criou obstáculos para o sucesso da reestruturação empresarial. Como esses créditos não se sujeitam à renegociação no plano de reestruturação apresentado pela empresa, eles continuam sendo exigidos segundo as regras estabelecidas em contrato ou lei, obrigando a recuperanda a manter os os desembolsos financeiros após o pedido de recuperação, sob pena de execução. A não sujeição desses créditos foi justificada pelos legisladores da época como necessária para contribuir com a redução gradual das elevadas taxas de juros praticadas no País, o que possibilitaria um ambiente de negócios mais favorável, porém isso nunca ocorreu (SALOMÃO; SANTOS, 2012, p.18)(ii). Para Manoel Justino (2013, p. 142)(iii), a Lei de Recuperação de Empresas deveria ser conhecida como "lei de recuperação do crédito bancário". Nos dados analisados da Serasa Experian, observa-se que o percentual de sucesso das recuperações no Brasil é muito baixo, em torno de $28 \%$. Traçando um paralelo com a lei americana, Chapter Eleven, em um estudo elaborado na Universidade da Califórnia em Los Angeles (UCLA) pelos pesquisadores Lynn LoPucki e Joseph Doherty, ambos da School of Law, que se propuseram a mapear fatores que têm impacto no sucesso de grandes companhias que buscaram a proteção legal, e cujo objetivo primordial era identificar possíveis mudanças necessárias no sistema para melhorar os índices de empresas recuperadas. "Das grandes empresas de capital aberto que querem permanecer nos negócios com recuperação judicial, apenas 70\% tiveram sucesso. Os ativos das outras 30\% são absorvidos por terceiros"(iv). Mesmo sendo muito superior ao nosso, os pesquisadores americanos ainda estudam soluções utilizando-se da Análise Econômica do Direito para obter resultados mais expressivos. Quanto ao Brasil, observa-se que as estatísticas apresentadas sobre recuperações judiciais são 
Personalidade Acadêmica Homenageada:

Augustus B. Cochran III (Agnes Scott College)

incipientes, não havendo base de dados robustas e fidedignas que possibilitem uma aplicação da Análise Econômica do Direito de forma mais efetiva. De modo geral, conclui-se do estudo que a Lei de Recuperação de Empresas, no formato atual, necessita de avanços para que alcance efetividade e cumpra com o dever constitucional de preservação da empresa e da sua função social.

PALAVRAS-CHAVE: Recuperação Judicial; Créditos; Não Sujeição.

\section{REFERÊNCIAS}

VILLAS BÔAS, Regina Vera; MARUCO, Fábia de Oliveira Rodrigues. Recuperação Judicial: Instrumento Jurídico de concretização da função social e ambiental da empresa e mantenedor da fonte geradora de empregos e das gerações presente e futuras. Revista Jurídica UNICURITIBA, n. 53, Curitiba, p. 357-377, 2018.

SALOMÃO, Luis Felipe; SANTOS, Paulo Penalva. Recuperação Judicial, Extrajudicial e Falência. Rio de Janeiro: Forense, 2012, p. 18.

BEZERRA FILHO, Manoel Justino. Lei de Recuperação de Empresas e Falência. $8^{\text {a }}$ ed. São Paulo: Revista dos Tribunais, 2013.

TMA - Turnaround Management Association. Estudo mostra fatores de sucesso na recuperação. Disponível em: <https://www.tmabrasil.org/materias/noticias-namidia/estudo-mostra-fatores-de-sucesso-em-recuperacao >. Acesso em: 23 jan. 2018. 